\title{
Community conservation: practitioners' answer to critics
}

Robert H. Horwich and Jonathan Lyon

\begin{abstract}
Based on ethical, theoretical and practical concerns, community-based conservation projects have developed over the past 2 decades as alternatives to traditional protected areas. Recent criticisms of such programmes by biologists and social scientists involve a debate on who should manage our natural resources. Such criticisms have focused on large integrated conservation and development projects (ICDPs) and have largely ignored the successes of small community conservation projects. Practitioners of ICDPs have also been disappointed with the results of their projects and are seeking answers from ICDP failures. Two important differences separate community conservation projects and ICDPs and have led to the success of the smaller projects: (1) community conservation projects see local
\end{abstract}

rural people as the solution to habitat degradation whereas ICDPs see them as the problem, (2) the scale of the smaller projects is at the community level but can use the same methods regionally, whereas ICDPs are large in scale and cost. We discuss, from a practitioner's viewpoint, the strengths that contribute to the successes of community conservation projects, including actually functioning at the community level, creating an empowered community group to carry on the social sustainability of the project, continuous basic level funding, and the importance of monitoring.

Keywords Belize, community conservation, communitybased conservation, ICDP, integrated conservation and development projects.

\section{Introduction}

Community-based conservation projects have developed over the past 2 decades as important alternatives to traditional protected areas that exclude humans. Establishment of these projects has been based on ethical, theoretical, and practical arguments by conservation practitioners and social scientists. Recently, however, there has been growing criticism of community-based conservation programmes and a call for renewed use of protected areas that exclude local communities from them and their management (Robinson, 1993; Brandon et al., 1998; Terborgh, 1999; Sanderson \& Redford, 2003, 2004; J. Oates \& T. Strusaker pers. comm., 2006). Evidence, however, shows that the success of protected areas is strongly correlated with a positive public attitude (Strusaker et al., 2005). Although initial criticism of community-based projects came from biologists (Oates, 1999; Terborgh, 1999) social scientists have also criticized how they perceive that conservationists, in general, treat local people when involving them in the

Robert H. Horwich (Corresponding author) Community Conservation, 50542 One Quiet Lane, Gays Mills, WI 54631, USA. E-mail ccc@mwt.net

Jonathan Lyon Department of Biology, Merrimack College, 315 Turnpike Street, North Andover, MA 01845, USA.

Received 17 October 2005. Revision requested 26 April 2006. Accepted 5 October 2006. conservation process, thus placing community conservation practitioners in an untenable situation (Belsky, 1999; Brechin et al., 2002).

Chapin (2004) criticized major conservation organizations and their integrated conservation and development projects (ICDPs) as 'generally paternalistic, lacking in expertise, and one-sided - driven largely by the agendas of the conservationists, with little indigenous input'. Although this stirred many responses (World Watch, 2005) Chapin's arguments were general, unproved, ambiguous narratives (Roe, 1991) such as contrasting 'fortress conservation' versus 'community conservation' (Adams \& Hulme, 2001). Chapin's (2004) criticisms lumped together all project types although most criticism has been directed towards ICDPs (Kiss, 2004; McShane \& Newby, 2004; McShane \& Wells, 2004; Sayer \& Wells, 2004; Wells et al., 2004), and even practitioners of ICDPs have been disappointed (Robinson \& Redford, 2004) and would like to learn from their failures (McShane \& Wells, 2004). The ensuing discussions, however, ignored smaller scale, successful community conservation projects that have moved beyond the narrative stage, through trial and error learning, and are achieving success. Our working definition of a community conservation project is one in which community members or a community-based organization are involved in efforts to protect or conserve the lands and environment they live on or nearby through the highest levels of participation, with the ultimate goal 
being management of the project by a local communitybased organization.

Whereas many critics of community conservation are sympathetic with the philosophy of such projects they cite implementation as the problem (Agrawal \& Gibson, 1999). However, two important differences separate community conservation projects and ICDPs that influence project implementation: (1) community conservation projects see local rural people as the solution to habitat degradation whereas ICDPs see them as the problem (McShane \& Newby, 2004; McShane \& Wells, 2004; Robinson \& Redford, 2004), and (2) the practical scale of small community projects is at the community level, whereas ICDPs are large in scale and finances. In addition, community conservation projects and similar forestry (Poffenberger et al., 1992; Shepard, 2004) and Participatory Rural Appraisal development projects (Chambers, 1994a,b, 1997) use the process approach to implementation, emphasizing 'experimentation, learning, adaptation, participation, flexibility, building local capacities and organic expansion' (Bond \& Hulme, 1999).

Here we attempt to illustrate to the international conservation and academic communities that the community conservation approach, while less known, is a successful alternative to ICDPs. The community conservation approach emphasizes community participation at the highest level, involving community ownership of projects, a scale that is small in size but adaptable and transferable to regional and national conservation efforts, and flexibility in working with all community stakeholders (indigenous or not) as well as with NGO and government partners. We illustrate this using specific examples from our own work.

\section{Strengths of a successful community conservation project}

\section{Scale of projects}

Most projects supported by large organizations, especially ICDPs, are large-scale and coupled with extensive financial support (Horta et al., 2002; Kiss, 2004) that is usually over a short lifespan (McShane \& Wells, 2004), whereas small-scale projects generally receive little support, financial or otherwise. Our experiences with the projects of Community Conservation and others (Stone \& D'Andrea, 2001; Borrini-Feyerabend et al., 2004) have shown us that to achieve success community conservation projects need to operate at small decentralized scales and involve small infusions of money for lengthy time spans. The negative correlation between the size of conservation projects and their effectiveness and success is supported by a report on the Global Environment Facility (GEF) projects that showed the programme had been a major failure except for the Small Grants Programme (Horta et al., 2002). It concluded that 'The mega-project approach to development resource transfers supported by donors, implementing agencies and external consultants must be abandoned... Successes such as the Small Grants Programme must be replicated, expanded and integrated throughout GEF operations and agencies' (Horta et al., 2002).

\section{Changing the scale}

There are two main points that involve scale and locality. Firstly, a successful community conservation project actually needs to work at a community scale. This may mean working with only one or a few villages or, in larger projects, it may mean dividing into meaningful village-based units. Brandon \& Wells (1992) noted that small, flexible, participatory projects could be models for ICDPs but in areas with a limited number of villages. For example, in Assam, India, we have been working regionally on the entire range of the golden langur Trachypithecus geei (c. 260,000 ha) by coordinating efforts of five regional NGOs that each focus on communities in specific areas within the species' range (Table 1). Collectively, the project works with over 130 villages and has integrated the training of villagers in Self Help Groups (NABARD, 2004) and Joint Forest Management committees or other forestry groups (Poffenberger \& McGean, 1996). The regional NGOs work with village groups on a personal level (Chambers, 1997). This project has been successful because it involves personal connections at the community level between individuals in the NGO and those in the village groups, and an integration of the Self Help Groups and the forestry committees. Measures of success are based on documenting the regenerating forest and increasing langur numbers, and interviews with villagers. Some village groups are now feeling sufficiently empowered to replant degraded forest, tend regenerating forest, patrol their forests, and repel encroachers both with and without the help of the Assam Forest Department. The NGOs are helping community groups to form regional federations surrounding some Reserve Forests. This project, although working regionally, is carried out at the community scale for a modest USD 20,000 annually.

Secondly, an important role for NGOs in any project is that they can help to create and strengthen communitybased organizations to prepare them to manage the project or key aspects of it. It is also important to strengthen regional NGOs, who must in turn be prepared to strengthen community groups to manage their own community projects and then to move on 
Table 1 Projects initiated or worked on by the NGO Community Conservation, showing the location and culture of the project, the year Community Conservation initiated the project or began work on it, the size of the area covered by the project, number of participating villages, and project outcomes (community groups formed, protected areas created, books published, education centres or museums created, public events conducted, and selected other outcomes such as habitat restoration, species reintroduction, major tourism income, and posters printed). All projects are ongoing at the time of writing.

\begin{tabular}{|c|c|c|c|c|c|c|c|c|c|c|c|}
\hline \multirow[b]{2}{*}{ Project } & \multirow[b]{2}{*}{ Country } & \multirow[b]{2}{*}{ Culture $^{1}$} & \multirow{2}{*}{$\begin{array}{l}\text { Year initiated } \\
\text { or *began } \\
\text { work }\end{array}$} & \multirow[b]{2}{*}{$\begin{array}{l}\text { No. of } \\
\text { villages }\end{array}$} & \multicolumn{7}{|c|}{ Project outcomes } \\
\hline & & & & & $\begin{array}{l}\text { Group } \\
\text { formed }\end{array}$ & $\begin{array}{l}\text { Protected } \\
\text { area created }\end{array}$ & $\begin{array}{l}\text { Area } \\
\text { (ha) }\end{array}$ & Book & $\begin{array}{l}\text { Education } \\
\text { centre }\end{array}$ & $\begin{array}{l}\text { Public } \\
\text { events }\end{array}$ & Other (selected) \\
\hline $\begin{array}{l}\text { Protect state endangered ornate box turtle } \\
\text { Terrepene ornata ornata \& dry prairie } \\
\text { habitat, reintroduction }\end{array}$ & USA & US & 1991 & NA & & & & & & & Box turtle reintroduction \\
\hline $\begin{array}{l}\text { Ferry Bluff Eagle Council: protection of bald } \\
\text { eagle Haliaeetus leucocephalus winter roosts } \\
\text { along Wisconsin River, ecotourism }\end{array}$ & USA & US & 1988 & 2 & Yes & & & & & Yes & $\begin{array}{l}\text { USD } 1,300,000 \text { in } \\
\text { ecotourism revenue } \mathrm{yr}^{-1}\end{array}$ \\
\hline $\begin{array}{l}\text { Kickapoo Valley Reserve: protection of lands } \\
\text { confiscated for dam project, endangered } \\
\text { northern remnant plants }\end{array}$ & USA & US & 1991 & 4 & Yes & Yes & 3,440 & & Yes & Yes & \\
\hline $\begin{array}{l}\text { Valley Stewardship Network: creation of river } \\
\text { stewardship group, water monitoring, } \\
\text { land use management, native brook trout } \\
\text { Salvelinus fontinalis }\end{array}$ & USA & US & 1994 & NA & Yes & & & Yes & & Yes & \\
\hline $\begin{array}{l}\text { Blue Mounds: conservation of endangered } \\
\text { species on private lands, prairie restoration }\end{array}$ & USA & US & 1995 & 6 & Yes & & 6,000 & & & Yes & \\
\hline $\begin{array}{l}\text { Badger Army Ammunition Plant lands: } \\
\text { protect grasslands from retired WWII } \\
\text { Ammunitions Plant lands, prairie restoration, } \\
\text { migratory grassland birds }\end{array}$ & USA & US & 1997 & 5 & Yes & Yes & 3,040 & Yes & & Yes & Prairie restoration \\
\hline $\begin{array}{l}\text { Kickapoo Organic Research Network: } \\
\text { encourage organic farming }\end{array}$ & USA & US & 1990 & NA & & & & Yes & & & \\
\hline $\begin{array}{l}\text { Community Baboon Sanctuary: conservation } \\
\text { of black howler monkey Alouatta pigra, } \\
\text { Central American river turtle Dermatemys } \\
\text { mawii \& other Belizean species, ecotourism }\end{array}$ & Belize & $\mathrm{Bz}, \mathrm{Cr}$ & 1984 & 7 & Yes & & 5,120 & Yes & Yes & Yes & Poster \\
\hline $\begin{array}{l}5 \text { Blues Lake National Park: protection of } \\
\text { scenic deep karst lake, wildlife protection, } \\
\text { ecotourism }\end{array}$ & Belize & Bz, Mest & 1991 & 1 & Yes & Yes & 1,680 & & Yes & Yes & \\
\hline $\begin{array}{l}\text { Gales Point: protection of west Indian manatee } \\
\text { Trichechus manatus \& other wildlife, community } \\
\text { protection of hawksbill turtle Eretmochelys } \\
\text { imbricata nesting beach, ecotourism }\end{array}$ & Belize & $\mathrm{Bz}, \mathrm{Cr}$ & 1991 & 1 & Yes & Yes & 28,000 & & & & \\
\hline $\begin{array}{l}\text { Temash River: protection of the best } \\
\text { mangrove forest in Belize }\end{array}$ & Belize & $\begin{array}{l}\text { Bz, G, Km, } \\
\text { Mest, Mm }\end{array}$ & 1994 & 6 & Yes & Yes & 14,921 & Yes & & $?$ & \\
\hline $\begin{array}{l}\text { Cockscomb Basin Wildlife Sanctuary: protection } \\
\text { of jaguar Panthera onca, other cats \& wildlife, } \\
\text { reintroduction of black howler monkey }\end{array}$ & Belize & $\mathrm{Mm}$ & *1992 & 2 & & Yes & 48,000 & Yes & Yes & & $\begin{array}{l}\text { Howler monkey } \\
\text { reintroduction }\end{array}$ \\
\hline
\end{tabular}

Rerry Bluff Eagle Council: protection of bald eagle Haliacetus leucocephalus winter roosts

Valley Stewardship Network: creation of river

lue Mounds: conservation of endangered

encourage organic farming

Trichechus manatus \& other wildlife, community

protection of hawksbill turtle Eretmochely

ecting beach, ecotourism

of black howler monkey 


\begin{tabular}{|c|c|c|c|c|c|c|c|c|c|c|c|}
\hline \multirow[b]{2}{*}{ Project } & \multirow[b]{2}{*}{ Country } & \multirow[b]{2}{*}{ Culture $^{1}$} & \multirow{2}{*}{$\begin{array}{l}\text { Year initiated } \\
\text { or *began } \\
\text { work }\end{array}$} & \multirow[b]{2}{*}{$\begin{array}{l}\text { No. of } \\
\text { villages }\end{array}$} & \multicolumn{7}{|c|}{ Project outcomes } \\
\hline & & & & & $\begin{array}{l}\text { Group } \\
\text { formed }\end{array}$ & $\begin{array}{l}\text { Protected } \\
\text { area created }\end{array}$ & $\begin{array}{l}\text { Area } \\
\text { (ha) }\end{array}$ & Book & $\begin{array}{l}\text { Education } \\
\text { centre }\end{array}$ & $\begin{array}{l}\text { Public } \\
\text { events }\end{array}$ & Other (selected) \\
\hline $\begin{array}{l}\text { Hicatee: conservation \& sustainable use of } \\
\text { endangered Central American river turtle } \\
\text { Dermatemys mawii }\end{array}$ & Belize & $\mathrm{Cr}$ & 1992 & 1 & Yes & $?$ & $?$ & & & & \\
\hline $\begin{array}{l}\text { Chacocente Reserve: protection of major } \\
\text { Nicaraguan olive ridley turtle Lepidochelys } \\
\text { olivacea nesting beach \& dry tropical forest }\end{array}$ & Nicaragua & Mest, $\mathrm{N}$ & *1997 & 4 & Yes & Yes & 4,224 & Yes & & & \\
\hline $\begin{array}{l}\text { Taldom: creation of protected wetlands area } \\
\text { complex for migrating common Eurasian cranes } \\
\text { Grus grus }\end{array}$ & Russia & Russian & 1994 & 1 & & Yes & 35,200 & Yes & Yes & & Poster \\
\hline $\begin{array}{l}\text { Nariva Swamp: protecting an important } \\
\text { Trinidad wetland }\end{array}$ & Trinidad & $\mathrm{Cr}, \mathrm{T}, \mathrm{WI}$ & *1997 & 2 & $?$ & Yes & 8,192 & & & & \\
\hline $\begin{array}{l}\text { Punta Laguna protection of Central American } \\
\text { spider monkey Ateles geoffroyi \& black howler } \\
\text { monkey, ecotourism }\end{array}$ & Mexico & $\mathrm{Ym}$ & *1989 & 1 & $?$ & Yes & 4,400 & & & & \\
\hline $\begin{array}{l}\text { El Salvador country-wide location of existing } \\
\text { Central American spider monkey populations \& } \\
\text { their protection }\end{array}$ & El Salvador & ES, Mest & 2001 & 4 & & Yes & 606 & & Yes & & \\
\hline $\begin{array}{l}\text { Huon-YUS (Yupna, Som \& Urawa Rivers): } \\
\text { protection of the Matschie's tree kangaroo } \\
\text { Dendrolagus matchiei \& other wildlife, creation of } \\
\text { a clan-based highland protected area }\end{array}$ & $\begin{array}{l}\text { Papua New } \\
\text { Guinea }\end{array}$ & Ya, Y & $* 2001$ & 13 & & Yes & 48,000 & Yes & & & \\
\hline $\begin{array}{l}{ }^{2} \text { Manas-west: protection of Ripu-Chirrang } \\
\text { Elephant Reserve \& major range of the } \\
\text { golden langur Trachypithecus geei }\end{array}$ & India & A, B, R & 1998 & 79 & Yes & Yes & 260,000 & Yes & & Yes & Posters \\
\hline $\begin{array}{l}{ }^{2} \text { Manas-Kakoijana: restoration of forest } \\
\text { habitat \& golden langur population in } \\
\text { Kakoijana Reserve Forest }\end{array}$ & India & $\mathrm{B}, \mathrm{Ga}, \mathrm{R}$ & 1998 & 28 & Yes & Yes & 260,000 & Yes & & Yes & Posters, reforestation \\
\hline $\begin{array}{l}{ }^{2} \text { Manas-Chakrashila: protection of Chakrashila } \\
\text { Wildlife Sanctuary, the largest southern 'island' } \\
\text { habitat for the golden langur, restoration of } \\
\text { Nadangiri Reserve Forest, creation of forest } \\
\text { corridor between Nadangiri \& Chakrashila } \\
\text { Wildlife Sanctuary }\end{array}$ & India & $\mathrm{B}, \mathrm{R}$ & 2001 & 30 & Yes & Yes & 260,000 & Yes & & Yes & Posters, reforestation \\
\hline $\begin{array}{l}{ }^{2} \text { Manas-Koila Moila: protection of the Manas } \\
\text { Reserve forest \& its golden langurs \& other } \\
\text { wildlife, ecotourism }\end{array}$ & India & A, B & 2002 & 1 & Yes & Yes & 260,000 & Yes & & Yes & Posters \\
\hline
\end{tabular}

${ }^{1}$ A, Assamese; B, Bodo; Bz, Belizean; Cr, Creole; ES, El Salvadorean; Ga, Garo; G, Garifuna; N, Nicaraguan; Km, Ketchi Maya; Mest, Mestizo; Mm, Mopan Maya; R, Rabha; T, Trinidad; US, United States; WI, West Indian; Y, Yupna; Ya, Yawan; Ym, Yucatecan Maya

${ }^{2}$ Manas Biosphere Reserve: 4 integrated projects for protection of the golden langur Trachypithecus geei and other wildlife and its forested habitat, cessation of major illegal logging, and reforestation 
to help other communities to develop conservation projects. Thus, NGOs must strive for 'working [them]selves out of a job' (quoted by an individual in Chapin, 2004).

We generated the term 'community conservation' (Lyon \& Horwich, 1996; Horwich \& Lyon, 1998) because when we began work in rural Belize in 1984, involving villagers in conserving their wildlife, it was the term that made the most sense given the small scale at which we were working. It was therefore also the name we chose for our NGO. Because the howler monkey Alouatta pigra being studied lived on the private lands of subsistence farmers, we had to work with and learn from the local villagers. In taking direction from them and their needs we found that we required skills for which our training in ethology and ecology had not prepared us. We had to become self-taught sociologists, anthropologists, entrepreneurs, tour guides, artisans, educators, policy makers, book writers, publicity agents, bookkeepers, grant-writers and fund-raisers in an effort to help community members become empowered community conservationists who could take over the project.

\section{What is community conservation?}

While our working definition of community conservation emphasizes conservation and local community ownership, there are many aspects of community conservation projects that contribute to their success and that differentiate them from ICDPs, e.g. working holistically, being flexible in implementation, and working at a small scale both spatially and financially. This often means initiating a project within a small rural area and expanding the project later. Although not acceptable to Chapin (2004), the words 'rural' and 'local' are appropriate if that is the location and scale at which conservation work is taking place. Community conservation can be done in culturally uniform indigenous villages, uniform non-indigenous villages, or villages with mixed cultures, including refugees to the country (Table 1). Conservation work is not precluded because a village is not culturally homogeneous. The key issue is whether a village (or its members), as a community, want to take responsibility to protect and benefit from its natural resources. Current global trends in economics, ecological degradation and movements of people therefore suggest that conservation may need to involve multiple cultures working to achieve conservation goals at community scales.

\section{Empowered community groups}

Although community participation has been inferred by the use of the terms 'community conservation', 'community-based conservation' or similar phrases, the nature and extent of participation is rarely clarified. A metric of grades of participation is shown in Fig. 1. Pretty (1995) describes a similar continuum in reference to people's participation in agriculture that ranges from manipulative and passive participation to selfmobilization, and notes that in a study of rural development in 41 African countries most participation was minimal. This continuum has been modified for use in conservation (Pimbert \& Pretty, 1997).

We strive for indigenous and co-management levels of participation (Fig. 1), with the goal of creating a group or institution to manage each conservation project (Murphree, 1994; Agrawal \& Gibson, 1999; Bond \& Hulme, 1999; Barrow \& Murphree, 2001). Co-management is valuable because it ensures that communities will protect their resources once they are completely managing them, yet maintain community ownership of the project. Murphree (1994) noted the importance that government institutions and NGOs play in the interactions with communities but that ICDPs focus on improving community relations rather than encouraging community propriety rights, stating that 'propriety schemes have a far greater chance of long-term success, because they provide the basis for conflict resolution between authorities of equal status in an open and transparent manner'. He further states 'thus ICDPs and community-based conservation initiatives are not necessarily synonymous. ICDPs can be purely relational in character, or they can be proprietary'.

Establishing an empowered independent communitybased institution strong enough to work collaboratively on an equal basis with government and non-government institutions to protect the community's interests and natural resources will facilitate success. Such an institution also facilitates social sustainability of projects. We have helped community participants create such institutions in Belize, Wisconsin and India, and they are functioning as independent, empowered groups who deal directly with government agencies, NGOs and illegal encroachers (Table 1).

Projects in two Reserve Forests (Nadangiri, which is part of the Chakrashila complex of lands, and Kakoijana; Table 1) in Assam, India, are examples of successful projects in which NGOs work with villages that encircle and protect the Forests from encroachers. Each village group located around Kakoijana Reserve Forest has a designated area of forest to protect. Jiaguri, a small Rabha tribal village, sends two men each morning to monitor 100 ha of forest. No encroachers have been found after one year of patrolling. The village of Chiponsila created a community-based organization that organized 200 villagers to patrol Kakoijana Reserve Forest, warning illegal woodcutters against 


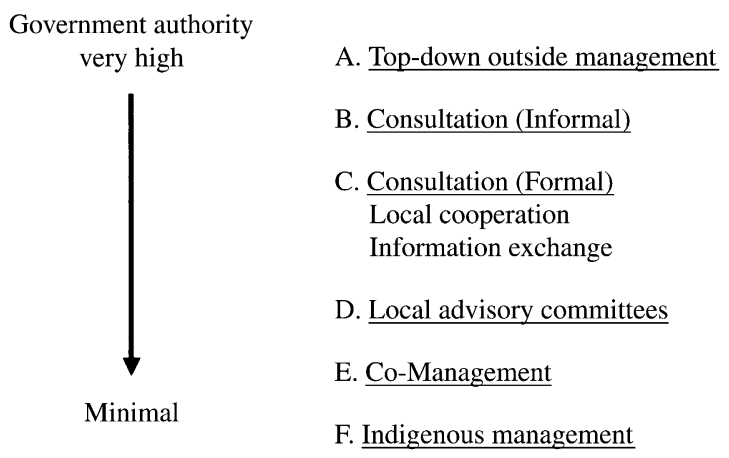

Community authority

minimal

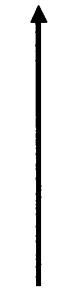

Very high

Fig. 1 The continuum of project participation and/or management (modified from Arnstein, 1969).

cutting wood and encouraging them in conservation activities.

Gendrabil, a Bodo tribal village adjacent to Chakrasila Wildlife Sanctuary replanted 5 ha and is protecting a regenerating sal Shorea robusta forest. As muntjac deer Muntiacus muntjak re-colonized the growing forest and attracted hunters, the villagers patrolled the forest, destroyed hunter hides and posted signs of ownership in the forest. This induced other villages to place their ownership signs in adjacent forests. Finally, Adivasi tribal women from Lalkura village, adjacent to Nadangiri Reserve Forest, stopped female encroachers from cutting fuelwood. When asked what they should do, the Lalkura women told them they should grow their own forest and then gave them fuelwood they had culled from their plantings.

In Belize the Community Baboon Sanctuary begun in 1985 has been financially and socially sustainable since 1990 (Table 1). In 1998, the local Women's Conservation Group assumed management, registered the sanctuary name, and secured grants for an education centre with computers and a restaurant whose profits are used for sanctuary management and for contributions to landowners and participating villages. They also run education programmes for children. The Community Baboon Sanctuary also catalysed other projects, and 12 communitybased organizations have signed co-management agreements with the Belize Forestry and Fisheries Departments (Young \& Horwich, in press). Some communities, such as St. Margaret's Village which manages 5 Blues Lake National Park (Table 1), have initiated the process to create protected areas. This revolution in thinking among rural Belize communities (Horwich \& Lyon, 1998; Belsky, 1999) is now integrated into government policy (Government of Belize, 2005) just as community conservation is shaping policy and practice in Africa (Hulme \& Murpree, 1999).

\section{Community conservation and Participatory Rural Appraisal}

When starting work in Belize in 1984 we were unaware of similar projects elsewhere and that we were intuitively developing a system focusing on conservation with integrated development using the same basic philosophy as Participatory Rural Appraisal, as being developed by others (Chambers, 1994a,b, 1997). Participatory Rural Appraisal is 'a family of approaches and methods to enable rural people to share, enhance, and analyse their knowledge of life and conditions, to plan and to act' (Chambers, 1994a,b). We define community conservation as helping communities become actively involved in protecting and benefiting from their natural resources, and this approach shares the following with Participatory Rural Appraisals: (1) a reversal from topdown to bottom up, (2) stimulating community awareness, (3) taking a facilitator role, (4) establishing community ownership of the project, (5) empowering rural people, (6) learning about the community and area from traditional knowledge, (7) treating local people as capable of managing their lives and natural resources, (8) treating local rural people with respect, and (9) working with flexibility and creativity (Chambers, 1994a,b). Whereas Participatory Rural Appraisals focus on natural resource management, agriculture, social economic programmes, and health/food security, our programmes focus on natural resources with an integration of agriculture and economic activities.

Campbell \& Vainio-Mattila (2003) maintain there are differences between community-based conservation and Participatory Rural Appraisals but their study focused on ICDPs, ignoring small projects. They noted that local ownership was low and that external agents encouraged only low levels of participation. They found few documented community-based conservation projects outside protected areas. In contrast to their findings, the 
Community Baboon Sanctuary's local ownership/ management in Belize has existed since 1990 with local participation from its inception (Horwich, 1990) and conserves private lands outside protected areas. We hope that the numerous case history publications (Horwich, 1990, 2005; Lyon \& Horwich, 1996; see Horwich \& Lyon, 1998, 1999 for listings), studies (Hartup, 1994; Bruner Lash, 2002), and TV and magazine publicity about the Community Baboon Sanctuary and other projects will help to guide future community conservation projects.

\section{Project money and other incentives}

Both large international conservation and in-country NGOs operate primarily in the realm of large grants and projects, and small budget community projects, regardless of their success, have not been held up as models of effective conservation (Horta et al., 2002). When considering involving communities in conservation, conservation organizations weigh economic incentives heavily, with the goal of alleviating poverty (Sanderson \& Redford, 2003; Brockington \& SchmidtSoltau, 2004; Roe \& Elliott, 2004). While important, economic incentives are not the only incentives poor people respond to (Campbell \& Vainio-Mattila, 2003). Social and cultural incentives are not given the importance they deserve (Uphoff \& Langholz, 1998). Our community conservation projects stress the sociality of groups, and the responsibility they have for managing their lives and natural resources, as well as the ethics of protecting their environment. When listening to villagers discuss their relationship with their natural environment we have rarely heard them talk about it relative to economics but rather in terms of its importance to their lives. RHH has listened, for example, to a so-called uneducated Indian villager talk about the interrelationships of life, and heard others tell about how they came together to protect the forest because they were 'forest people'.

\section{The bottom line of success: biodiversity monitoring}

A major criticism of community conservation projects is that limited financial and human resources, when focused on poverty alleviation, will lead to a major reduction in biodiversity (Sanderson \& Redford, 2003). Others have argued for a balance between conservation and development (Brockington \& Schmidt-Soltau, 2004) that could be achieved through protected area co-management between local communities and government or other governance structures (Roe \& Elliott, 2004). It is not clear, however, how much monitoring of project outcomes is actually taking place. Our small community conservation projects, for example, have not been adequately monitored because of lack of funds, but even large projects with huge budgets are weak in monitoring and evaluation (Horta et al., 2002).

Although balanced project evaluation is important, in most of our projects (Table 1) we lack definitive data. For example, at Gales Point, Belize, the hawksbill turtle Eretmochelys imbricata protection programme has been releasing c. 12,000 hawksbill hatchlings each year since 1992. Although there are no studies on the adult population, results will not become apparent until the survivors breed as adults over 30 years later.

However, in the Community Baboon Sanctuary project in Belize we have data indicating that the howler monkey population increased from 800 animals in 1985 to c. 4,400 in 1999 (Horwich et al., 2001). A later census of two-thirds of the Sanctuary in 2002, carried out by villagers, estimated the population at 3,000-5,000 (Brockett, 2003). Additionally, 62 howler monkeys Alouatta pigra were translocated from the Sanctuary in 1992-1994 to the Cockscomb Basin Wildlife Sanctuary where they had been locally extirpated in the 1970s. From the monitoring of that population (Horwich et al., 2002) it was shown that the population had grown to $>100$ animals by 1997 with the potential to reach 400-500 monkeys by the time of writing (Horwich et al., 2002). A survey in 2007 indicated that the population had more than doubled since 1997 (F. Koontz, pers. comm.).

We have initiated similar monitoring of the golden langur population in two Indian Reserve Forests (Kakoijana Reserve Forest, and Koila Moila, in Manas Reserve Forest). In Kakoijana Reserve Forest a complete census in 2004-2005 indicated a total population of 237 langurs. A partial survey 8 years earlier estimated a population of $60-80$ monkeys. A second census in 2006-2007 is expected to indicate a further increase because a number of pregnant females were observed in the 2004-2005 survey (A. Bose, pers. comm., 2006).

What is important in all of this project monitoring is that the villagers have been involved. At the Community Baboon Sanctuary in 2002 villagers carried out the census on their own initiative and with some outside help. When howler monkeys were translocated from the Community Baboon Sanctuary to the Cockscomb Basin Wildlife Sanctuary, villagers from the adjacent village of Maya Centre carried out radio telemetry monitoring of translocated howler monkeys for 4 years (Horwich et al., 2002). In Gales Point, Belize, villagers were involved in forest inventories, documenting tree phenology and monitoring fish populations. In addition, villagers aided the Wildlife Conservation Society by tracking radio-collared manatees. They have also recorded data on hawksbill marine turtle nesting and have been 
managing the project since 1992. New Horizons, an Assamese community-based organization from Koila Moila has censused a study area, recording 327 langurs (Table 1).

\section{Conclusions}

Conservation needs to refocus on low budget, community-scale projects, and on the wealth of ongoing community conservation projects. A glimpse of numerous projects ongoing internationally is available (IUCN, 2003; Borrini-Feyerabend et al., 2004) but most are not presented by the practitioners themselves and have not been fully evaluated. Thus, although there appears to be a wide-range of small-scale community projects taking place, few details are available. We also need to reset our evaluation focus, our funding focus, and our NGO focus to include community-scale projects. Until this is done academic debates on the worthiness, validity and success of community-based conservation projects will remain peripheral at best, and detrimental at worst. Jointly developing evaluation criteria that reflect the community scale is a first step. The debate on community conservation should be rooted in the concept of community, and must be inclusive.

This approach sees rural community members as potential conservationists and asks their help to protect their environment. Thus, while the academic debate continues over whether to exclude communities and indigenous peoples from the conservation process and from protected areas, rural community conservationists worldwide are protecting their natural resources while maintaining their livelihoods. They are rural residents and members of small, regional NGOs that move ahead on small grants, donations, fund-raising events and most of all, on volunteer labour. They continue their work, often oblivious to the controversies and without access to conservation journals.

We believe therefore that, despite how conservation fashions and associated funding fluctuates, community conservation is the future of conservation. When carried out with the right tools, at the community scale, and at the appropriate financial scale, most projects will succeed. In places such as Asia there is no doubt that community conservation is the future because to ignore the vast populations of people living adjacent to and within many forests and other habitats is to ignore the inevitable and the ultimate failure of conservation. Community conservation practitioners and small-scale community conservation projects deserve the conservation establishment's focus, attention and support. They represent one of our best chances for conservation success.

\section{Acknowledgements}

We would like to thank all of the community members who have taught us how to carry out successful community conservation projects, with a special thanks to the residents of rural Belize, Assam and Wisconsin. We would also like to thank Cynthia Olmstead for her comments on the manuscript. Finally, we thank WWF, the National Geographic Society, Scott Neotropical Fund, USAID and GEF for funding in Belize, the Margot Marsh Biodiversity Foundation and Primate Conservation Inc. for funding in Assam, and Wisconsin state agencies and Trout Unlimited for funding in Wisconsin.

\section{References}

Adams, W. \& Hulme, D. (2001) Conservation \& community changing narratives, policies \& practices in African conservation. In African Wildlife \& Livelihoods (eds D. Hulme \& M. Murphree), pp. 9-23. James Currey, Oxford, UK.

Agrawal, A. \& Gibson, C.C. (1999) Enchantment and disenchantment: the role of community in natural resource conservation. World Development, 27, 629-649.

Arnstein, S.A. (1969) A ladder of citizen participation. Journal of the American Institute of Planners, 35, 216-224.

Barrow, E. \& Murphree, M. (2001) Community conservation from concept to practice. In African Wildife \& Livelihoods (eds D. Hulme \& M. Murphree), pp. 24-37. James Currey, Oxford, UK.

Belsky, J.M. (1999) Misrepresenting communities: the politics of community-based rural ecotourism in Gales Point Manatee, Belize. Rural Sociology, 64, 641-666.

Bond, R. \& Hulme, D. (1999) Process approaches to development: theory and Sri Lankan practice. World Development, 27, 1339-1358.

Borrini-Feyerabend, G., Pimbert, M., Farvar, M.T., Kothari, A. \& Renard, Y. (2004) Sharing Power. Learning-by-Doing in Co-management of Natural Resources Throughout the World. IIED and IUCN/CEESP/CMWG, Cenesta, Tehran.

Brandon, K.E., Redford, K.H. \& Sanderson, S.E. (eds) (1998) Parks in Peril: People, Politics and Protected Areas. Island Press/The Nature Conservancy, Washington, DC, USA.

Brandon, K.E. \& Wells, M. (1992) Planning for people and parks: design dilemmas. World Development, 20, 557-570.

Brechin, S.R., Wilshusen, P.R., Fortwangler, C.L. \& West, P.C. (2002) Reinventing a square wheel: a critique of the new protectionist paradigm in international biodiversity conservation. Society and Natural Resources, 15, 41-64.

Brockett, R. (2003) 2003 Howler monkey census. In The Common Flora \& Fauna of the Community Baboon Sanctuary (ed. C. Young), pp. 63-65. UNDP, GEF Small Grants Programme, Belize City, Belize.

Brockington, D. \& Schmidt-Soltau, K. (2004) The social environmental impacts of wilderness and development. Oryx, 38, 140-142.

Bruner Lash, G.Y. (2003) Sustaining our spirit: ecotourism on privately owned rural lands and protected areas. $\mathrm{PhD}$ thesis, University of Georgia, Athens, USA.

Campbell, L.M. \& Vainio-Mattila, A. (2003) Participatory development and community-based conservation: 
opportunities missed for lessons learned? Human Ecology, 31, 417-437.

Chambers, R. (1994a) The origins and practice of Participatory Rural Appraisal. World Development, 22, 953-969.

Chambers, R. (1994b) Participatory Rural Appraisal (PRA): analysis of experience. World Development, 22, 1253-1268.

Chambers, R. (1997) Editorial: Responsible well-being a personal agenda for development. World Development 25, 1743-1754.

Chapin, M. (2004) A challenge to conservationists. World Watch, Nov./Dec., 17-31.

Government of Belize (2005) The Belize National Protected Areas System Plan. Ministry of Natural Resources and the Environment, Belmopan, Belize.

Hartup, B.K. (1994) Community conservation in Belize: demography, resource use, and attitudes of participating landowners. Biological Conservation, 69, 235-241.

Horta, K., Round, R. \& Young, Z. (2002) The Global Environmental Facility, The First Ten Years - Growing Pains or Inherent Flaws? Http:/ / www.environmentaldefense.org [accessed 1 May 2006].

Horwich, R.H. (1990) How to develop a community sanctuary an experimental approach to the conservation of private lands. Oryx, 24, 95-102.

Horwich, R.H. (2005) Communities saving Wisconsin birds: north and south. Passenger Pigeon, 67, 85-98.

Horwich, R.H., Brockett, R.C., James, R.A. \& Jones, C.B. (2001) Population structure and group productivity of the Belizean black howling monkey (Alouatta pigra): implications for female socioecology. Primate Report, 61, 47-65.

Horwich, R.H., Koontz, F., Saqui, E., Ostro, L., Silver, S. \& Glander, K. (2002) Translocation of black howler monkeys in Belize. Re-introduction News, 21, 10-12.

Horwich, R.H. \& Lyon, J. (1998) Community-based development as a conservation tool: the Community Baboon Sanctuary and the Gales Point Manatee Project. In Timber, Tourists, and Temples: Conservation and Development in the Maya Forest of Belize, Guatemala, and Mexico (eds R.B. Primack, D. Bray, H.A. Galetti \& I. Ponciano), pp. 343-363. Island Press, Washington, DC, USA

Horwich, R.H. \& Lyon, J. (1999) Rural ecotourism as a conservation tool. In Tourism Development in Critical Environments (eds T.V. Singh \& S. Singh), pp. 102-119. Cognizant Communication Corporation, New York, USA.

Hulme, D. \& Murphree, M. (1999) Communities, wildlife and the 'new conservation' in Africa. Journal of International Development, 11, 277-285.

IUCN (Commission on Environmental, Economic \& Social Policy) (2003) Community empowerment for conservation. Policy Matters, 12, 1-253.

Kiss, A. (2004) Making biodiversity conservation a land-use priority. In Getting Biodiversity Projects to Work (eds T.O. McShane \& M.P. Wells), pp. 98-123. Columbia University Press, New York, USA.

Lyon, J. \& Horwich, R.H. (1996) Modification of tropical forest patches for wildlife protection and community conservation in Belize. In Forest Patches in Tropical Landscapes (eds. J. Schelhas \& R. Greenberg), pp. 205-230. Island Press, Washington, DC, USA.

McShane, T.O. \& Newby, S.A. (2004) Expecting the unattainable: the assumptions behind ICDPs. In Getting Biodiversity Projects to Work (eds. T.O. McShane \& M.P. Wells), pp. 49-74. Columbia University Press, New York, USA.
McShane, T.O. \& Wells, M.P. (2004) Integrated conservation and development? In Getting Biodiversity Projects to Work (eds. T.O. McShane \& M.P. Wells), pp. 3-9. Columbia University Press, New York, USA.

Murphree, M.W. (1994) The role of institutions in community-based conservation. In Natural Connections (eds D. Western, R.M. Wright \& S.C. Strum), pp. 403-427. Columbia University Press, New York, USA.

NABARD (National Bank for Agriculture and Rural Development) (2004) A Handbook on Forming Self-Help Groups (SHGs). NABARD, Mumbai, India.

Oates, J.F. (1999) Myth and Reality in the Rain Forest: How Conservation Strategies Are Failing in West Africa. University of California Press, Berkeley, USA.

Pimbert, M.P. \& Pretty, J.N. (1997) Parks, people and professionals: putting 'participation' into protected-area management. In Social Change \& Conservation (eds K.B. Ghimire \& M.P. Pimbert), pp. 297-330. Earthscan Publications Ltd, London, UK.

Poffenberger, M. \& McGean, B. (eds) (1996) Village Voices, Forest Choices: Joint Forest Management in India. Oxford University Press, Delhi, India.

Poffenberger, M., McGean, B., Khare, A. \& Campbell, J. (1992) Community Forest Economy and Use Patterns: Participatory Rural Appraisal (PRA) Methods in South Gujarat, India. Society for Promotion of Wastelands Development, New Delhi, India.

Pretty, J.N. (1995) Participatory learning for sustainable agriculture. World Development, 23, 1247-1263.

Robinson, J.G. (1993) The limits to caring: sustainable living and the loss of biodiversity. Conservation Biology, 7, 20-28.

Robinson, J.G. \& Redford, K.H. (2004) Jack of all trades, master of none: inherent contradictions among ICD approaches. In Getting Biodiversity Projects to Work (eds T.O. McShane \& M.P. Wells), pp. 10-34. Columbia University Press, New York, USA.

Roe, E.M. (1991) Development narratives, or making the best of blueprint development. World Development, 19, 287-300.

Roe, D. \& Elliott, J. (2004) Poverty reduction and biodiversity conservation: rebuilding bridges. Oryx, 38, 137-139.

Sanderson, S.E. \& Redford, K.H. (2003) Contested relationships between biodiversity conservation and poverty alleviation. Oryx, 37, 389-390.

Sanderson, S. \& Redford, K. (2004) The defense of conservation is not an attack on the poor. Oryx, 38, 146-147.

Sayer, J. \& Wells, M.P. (2004) The pathology of projects. In Getting Biodiversity Projects to Work (eds T.O. McShane \& M.P. Wells), pp. 35-48. Columbia University Press, New York, USA.

Shepard, G. (2004) Poverty and forests: sustaining livelihoods in integrated conservation and development. In Getting Biodiversity Projects to Work (eds T.O. McShane \& M.P. Wells), pp. 340-371. Columbia University Press, New York, USA.

Stone, R.D. \& D'Andrea, C. (2001) Tropical Forests and the Human Spirit. University of California Press, Beerkeley, CA.

Strusaker, T.T., Strusaker, P.J. \& Siex, K.S. (2005) Conserving Africa's rain forests: problems in protected areas and possible solutions. Biological Conservation, 123, 45-54.

Terborgh, J. (1999) Requiem for Nature. Island Press, Washington, DC, USA. 
Uphoff, N. \& Langholz, J. (1998) Incentives for avoiding the Tragedy of the Commons? Environmental Conservation, 25, 251-261.

Wells, M.P., McShane, T.O., Dublin, H.T., O'Connor, S. \& Redford, K.H. (2004) The future of integrated conservation and development projects: building on what works. In Getting Biodiversity Projects to Work (eds T.O. McShane \& M.P. Wells), pp. 398-421. Columbia University Press, New York, USA.

World Watch (2005) A challenge to conservationists: phase II. World Watch, Jan./Feb., 5-20.

Young, C. \& Horwich, R.H. (in press) People and protected areas: history of protected areas and co-management in Belize. In Taking Stock: The First 25 Years of Belizean Independence (eds B. Balboni \& J. Palacio). Cubola Productions, Benque Viejo del Carmen, Belize.

\section{Biographical sketches}

Rob Horwich is the Director of Community Conservation and has been involved since 1984 in over 20 ongoing community conservation projects in nine countries, with a current focus in Belize, Assam, India and USA. His research interests are in primate behaviour, ecology and populations. He has reintroduced a population of howler monkeys in Belize and developed a technique for successful reintroduction of threatened cranes. Jon Lyon has conducted research on forest ecology, riparian plant ecology, plant-soil relationships, invasive plant ecology and freshwater water quality. He has worked with Community Conservation for nearly 2 decades and has been involved in several community conservation projects. 